Florida International University FIU Digital Commons

FIU Electronic Theses and Dissertations

University Graduate School

7-29-2018

\title{
Promoting Peace Amid the Terror: The Work of the Ahmadiyya in Miami
}

Emmanuel Dennis

Florida International University, edenn013@fiu.edu

DOI: 10.25148 /etd.FIDC006894

Follow this and additional works at: https:// digitalcommons.fiu.edu/etd

Part of the Islamic Studies Commons

\section{Recommended Citation}

Dennis, Emmanuel, "Promoting Peace Amid the Terror: The Work of the Ahmadiyya in Miami" (2018). FIU Electronic Theses and Dissertations. 3743.

https://digitalcommons.fiu.edu/etd/3743

This work is brought to you for free and open access by the University Graduate School at FIU Digital Commons. It has been accepted for inclusion in FIU Electronic Theses and Dissertations by an authorized administrator of FIU Digital Commons. For more information, please contact dcc@fiu.edu. 


\title{
FLORIDA INTERNATIONAL UNIVERSITY
}

Miami, Florida

PROMOTING PEACE AMID THE TERROR: THE WORK OF THE AHMADIYYA IN MIAMI

\begin{abstract}
A thesis submitted in partial fulfillment
of the requirement for the degree of
\end{abstract}

MASTER OF ARTS

in

RELIGIOUS STUDIES

by

Emmanuel Dennis 


\section{To: Dean John F. Stack Jr.}

Steven J. Green School of International and Public Affairs

This thesis, written by Emmanuel Dennis, and entitled Promoting Peace Amid the Terror: The Work of the Ahmadiyya in Miami, having been approved in respect to style and intellectual content, is referred to you for your judgment.

We have read this thesis and recommend that it be approved.

$\begin{array}{r}\hline \text { Steven Vose } \\ \hline \text { Iqbal Akhtar } \\ \hline \text { Albert Wuaku, Major Professor }\end{array}$

Date of Defense: June 29, 2018

The thesis of Emmanuel Dennis is approved.

Dean John F. Stack Jr. Steven J. Green School of International and Public Affairs

Andres G. Gil

Vice President for research and Economic Development and Dean of the University Graduate School

Florida International University, 2018 


\section{DEDICATION}

I dedicate this thesis to the leadership and members of the Ahmadiyya Muslim Community. Their willful contribution and participation ensured that this study became complete. Their efforts and dedication are so appreciated. I also want to remember Jalal Malik and pray that you recover much faster. I stood by your side as we handed out fliers, books and other paraphernalia at the Miami Book Fair. It was great to be there with you. Get well soon! 


\section{ACKNOWLEDGMENT}

I am sincerely grateful to Professors Steven Vose, Iqbal Akhtar and Albert Wuaku, my major Professor for this thesis. They have worked with me on this thesis with so much patience and support to have this study complete. The regular feedback I received from Professor Steven Vose was so useful for bringing out more clarity to the thesis. His additions to several parts of the thesis opened fresh perspectives for consideration. I am grateful for your help and the help of Professor Iqbal Akhtar. I received a lot of help from the many perspectives you shared with me on the thesis which broadened my view on the work and the various angles to consider in conducting the research. The contact information I received from you was of immense help. Thank you, Professors Vose and Akhtar for helping me discover the Ahmadiyya community. I also wish to show a great appreciation to Professor Albert Wuaku. He helped shape the study and guided my writing with each stage, often pointing me to areas I missed. He has been of great help since the beginning of my studies here and I have been excited to be under his tutelage and guidance. Thank you so much, Prof!

My sincere gratitude to the entire faculty of the Religious Studies Department and my colleagues in Graduate School with whom I shared many good moments. I also appreciate the help and friendship of the department's staff, Luz Aviles and Yusimi Sayus, who helped me with my first words in Spanish. Muchas Gracias! I finally wish to say thank you to Fareed Zafar, one of the leaders in the Ahmadiyya Muslim Community and a key informant for the study. Thank you for the many times we spoke together and especially the long day I traveled to meet you in Hallandale. 
You welcomed me and discussed with me whatever I needed to know and thank you for the cricket match! I can watch and play cricket now. 


\author{
ABSTRACT OF THE THESIS \\ PROMOTING PEACE AMID THE TERROR: THE WORK OF THE \\ AHMADIYYA IN MIAMI \\ by \\ Emmanuel Dennis
}

Florida International University, 2018

Miami, Florida

Professor Albert Wuaku, Major Professor

This study examines the argument that Islam is far removed from violence in any form. It also delves into the discussion that many of the terrorist activities that have been carried out in America have much to do with homegrown terrorism than those related to Islam.

At the center of this research is the Ahmadiyya Muslim Community which sees itself as an authentic form of Islam attuned to American values and offering a concise and rational version of Islam. This study explores the various outreach initiatives and activities of the Ahmadiyya that supports the counter-narrative that Islam does not condone violence.

Following the various engagements and activities by the Ahmadiyya that are conducted both online and physically with the Hispanic and African community in Miami, the study concludes that the counter-narrative of Islam by the Ahmadiyya is far from the violence perpetrated in its name. 


\section{TABLE OF CONTENTS}

CHAPTER

PAGE

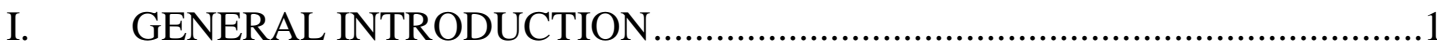

II. THEORETICAL FRAMEWORK ...........................................................

III. FIELDWORK AND METHOD OF DATA COLLECTION ........................14

The AhMAdiYya COMMUNity AND GEOGRAPHICAL SETTING ...................... 15

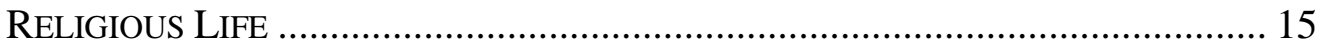

PARTICIPANT OBSERVATION ................................................................... 16



IV. LITERATURE REVIEW AND CONTRIBUTION OF THE STUDY ..........19

UNDERSTANDING ISLAMOPHOBIA ............................................................ 19

THE RESPONSE TO ISLAMOPHOBIA ......................................................... 28

AHMADIYYA IN AMERICA ...................................................................... 30

V. AHMADIYYA IN MIAMI - THE PHYSICAL TEMPLE, THE COMMUNITY AND ITS HISTORY ..................................................... 34

THE BAITUL NASEER MASJID .................................................................... 35

THE COMMUNITY AND ITS HISTORY ......................................................... 37

VI. THE DISCOURSE AND ACTIVITIES OF THE AHMADIYYA IN MIAMI



HEARING IMAM HANEEF SPEAK TO THE FIU PUBLIC .................................... 40





ENGAGING THE ONLINE COMMUNITY ..................................................... 48

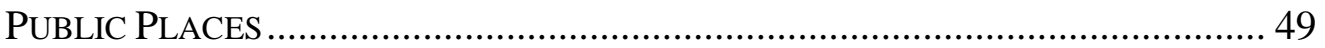

INVOLVEMENT WITH THE PUBLIC ............................................................. 50



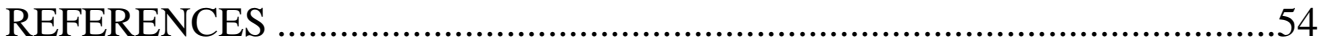




\section{CHAPTER I}

\section{GENERAL INTRODUCTION}

The public perception of Islam became increasingly warped after the 9/11 attacks in the United States. The word "terrorism" became associated with Islam. The fact that radical Islamic agents sponsored this attack gave birth to Islamophobia. Islamophobia describes prejudice in many forms against Muslims and those perceived to be Muslims. ${ }^{1}$ Following the 9/11 attacks, other violent events in the United States were touted as terrorism and linked with Islam, spurring more hatred for Muslims. Outside the USA, many violent acts carried out by individuals belonging to Islamic terrorist groups such as the Islamic State (ISIS) and $\mathrm{Al}$ Qaeda, bolstered these negative sentiments against Islam. Today Islamophobia is further enhanced when the media reports violence carried out by lone attackers or terrorists who identify themselves with Islam. A dominant narrative that Islam promotes violence and is not in sync with American values, has become a lens through which the American public now views the religion.

In response, Muslims in the United States have been pushed to present a positive image of themselves to the public. The Ahmadiyya, a Muslim minority sect, is one of these groups. As a community it has identified the need to engage the American public, using many initiatives such as interfaith dialogue, community outreach initiatives, and teachings,

\footnotetext{
${ }^{1}$ Todd Green. The Fear of Islam. (Minneapolis: Fortress Press, 2015), 13.
} 
to inform it about Islam and to change the general perception of the religion as a violent one. $^{2}$

This study is about some of the initiatives the Ahmadiyya has been preoccupied with, in a bid to present itself as an Islamic form with values and practices compatible with Western culture and society. This is a way this sect of Islam tries to combat the challenge of Islamophobia in the United States. The focus of the study is the Ahmadiyya Muslim Community in South Florida. The study investigated the outreach initiatives and discourses of this portion of Ahmadis in post 9/11 2001 America. In its present location at Hallandale Beach in South Florida, the Masjid, as members refer to the Mosque, is home to Ahmadis in this part of the USA. Many of its members are Hispanics and African Americans. The Mosque is also the regional headquarters of Ahmadi Muslims in the southern parts of the United States and the Caribbean. The name of the Masjid is Baitul Naseer Mosque. One activity that stands out among many in this Mosque is its interfaith dialogue sessions. Interfaith dialogue describes meetings of people of other religious faiths at the Ahmadiyya mosque. At these meetings all participants are encouraged to share their views about Islam and other pertinent questions facing society in general. These fora create an opportunity for discourse on Islam and on issues that are foundational in all religions such as justice, peace, and service to humanity. The dialogues help to clarify to many who participate the nature of Islam, especially as the Ahmadis understand it. The Ahmadis, who convene these meetings make a point of demonstrating how, as a religion Islam - does not stand with the violence done in its name. As a sect Ahmadis have always distinguished themselves as an

${ }^{2}$ Simon Ross Valentine. Islam and the Ahmadiyya Jama'at. (New York: Columbia University Press, 2008), 19. 
Islamic tradition that is more in tune with modern Western values, than other schools of Islam. In south Florida the Baitul Naseer Mosque engages in many outreach programs are aimed at promoting this image of Islam. These outreach initiatives also offer the Mosque avenues to interact further with the larger South Floridian community, establish its presence as a religious group, and provide services to the diverse populations that live in South Florida. The community also uses online social media platforms such as Twitter and Periscope, to disseminate information that sheds a more positive light on Islam.

This study builds on findings from my field investigation into these outreach initiatives and discourse of the Ahmadiyya Muslim Community in Hallandale. The primary site of this project was the Masjid at Hallandale Beach, Baitul Naseer Mosque. This study used ethnographic methods. These included unstructured interviews, face to face interactions and participant observation.at the primary site. These methods were also employed at the Miami Book Fair in Miami, a Blood Donation Exercise in Fort Lauderdale, and a Coffee Hour in North Miami. I consider these to be secondary sites for the collection of data. The interviews involved the leadership and members of the Ahmadiyya in these various locations. The interviews spanned the history of the Ahmadiyya in South Asia and South Florida and the challenges the link between Muslims, Islam and terrorism after 9/11 has posed for the community and the nature of their outreach programs. This study also involved listening to sermons and participating in Coffee Hour meetings hosted by Imams of this community. This study involved gathering data on the Ahmadiyya's history in Miami, the composition of its membership, its teachings and how it is shaping these teachings to its own needs in the American public. In all, the study explored how the 
Ahmadis position themselves vis a vis traditional forms of Islam and how they respond to the contemporary American distrust of Islam.

The main thrust of my argument in this study is that the post 911 Islamophobic atmosphere in the USA paradoxically has augured well for the Ahmadiyya. Considered by schools that view themselves as orthodoxies, to be a deviant form of Islam, the Ahmadiyya has over the years struggled for legitimacy in the Islamic world. As a community, it has it has always presented itself as a sect of Islam that is compatible with Western and modern values. The environment of Islamophobia in the USA has given the Ahmadiyya a new impetus to promoting itself as a pro-Western Islamic tradition. Islamophobia has become a foil against which the Ahmadiyya is demonstrating its identity as pro-Western, open to dialogue and a peace-promoting and progressive form of Islam. In other words, Islamophobia has furnished the Ahmadiyya with a stage on which to promote itself as a form of Islam different from other Islamic school's popular imagination links with terrorism and to present itself as a sect of Islamic that is compatible with Western values. An identity that had disadvantaged the Ahmadis in the Islamic world has become the basis of its expansionist initiatives. This study demonstrates the initiatives and discourses that show how this sect it not only shaping itself to the Islamophobic atmosphere in the USA but taking advantage of it.

This study has been divided into seven chapters. Chapter 1 is the introduction to the study. In Chapter 2, the theories of Michael Warner, Said, and Dabashi are explored in relation to fieldwork data gathered for the research. Chapter 3 is the fieldwork. This chapter explores the location of the study, the people interviewed, challenges of the study and the questions posed to the interviewees. Chapter 4 recounts literature on the Ahmadiyya, how 
they are recasting themselves in post 9/11 America and how these activities by the Ahmadiyya are unfolding in the United States. In Chapter 5 of this study, I describe the Ahmadiyya in Miami. This involves the Masjid, the Ahmadiyya community, and its history. Chapter 6 examines the discourse and teachings of the Ahmadiyya and how it reflects my argument in this study. I describe how the activities and outreach programs of the Ahmadiyya demonstrate my argument in this research. Chapter 7 concludes the study and presents additional topics for future research. I demonstrate by restating my argument and how my results support this study. 


\section{CHAPTER II}

\section{THEORETICAL FRAMEWORK}

The argument I have advanced in this study leads me to two major theoretical models. These are Edward Said's Orientalism and the scholarly perspective that draws on the idea of the religious market as a metaphor in analyzing the behavior of religious communities and their agents in a pluralistic religious space. I will discuss these ideas on their own. But I will also show how they interact meaningfully as a frame of ideas that can help us to understand the initiatives and the discourses of the Ahmadiyya community in South Florida theoretically.

Western perceptions of the East and traditions of eastern provenance are largely shaped by stereotypes about the cultures and lives of the people residing there. ${ }^{3}$ Edward Said described this practice as Orientalism. He depicted how the colonial images and stereotypes of Eastern cultures form the views that many people in the West have about the East. ${ }^{4} \mathrm{He}$ explained that knowledge about the Orient or the East was not only through army conquest or colonial control but, also sustained through literature, anthropology, and other narratives. The cultures of the East are viewed to be inferior to those of the West. Said further explained that these forms of stereotypes that described the East portray the people in ways that agree with the West's perception of the East. The sense often conveyed is that the West is more sophisticated and superior to the East or the Orient. ${ }^{5}$ The Orientalist

\footnotetext{
${ }^{3}$ Edward Said. Orientalism. (New York: Vintage Books, 1979), 17.

${ }^{4}$ Ibid, 23.

${ }^{5}$ Ibid.
} 
narrative is that cultures and peoples of the East have qualities that render them incomparable to the cultures of the West. ${ }^{6}$ As an Eastern religion, Islam is a part of the traditions viewed from the Orientalist perspectives. These depictions by Said are not farfetched because they describe general notions of some people in the American public about Islam. Countries such as Pakistan, Saudi Arabia, Iran, Afghanistan, Malaysia, and Bangladesh practise Islam. Because of the culture and religion in these places, some scholars such as Paul Scheffer view Islam and the cultures of these places as inferior to the West. This view agrees with the Orientalist perspective by Said about the West's view of the East. The cultures of these countries are considered by many people in the United States to stifle freedoms of the people living there, to favor patriarchy and have misogynist views, and to have oppressive forms and systems of government. ${ }^{7}$ Generally, women in Islam are identified by many in the United States by their Hijab, Niqab, and Burqas. This type of clothing covers parts or entire bodies of Muslim women. Many people in US view these modes of dressing as inferior and expressive of an existing patriarchy in these countries. Muslim women are considered "trapped" and unable to live freely. They are considered subservient to Muslim men and do not have enough avenues of expression. ${ }^{8}$ Muslim men are also identified by the Kufi and Taqiyah caps they wear together with their beards and robes. For many people in the United States these are markers of the inferiority of the cultures of the East in comparison to their value system. The sense is that the religion of Islam depicts a culture that hinders freedom of speech and supports oppressive regimes

\footnotetext{
${ }^{6}$ Ibid.

${ }^{7}$ Todd Green. The Fear of Islam. (Minneapolis: Fortress Press, 2015), 81.

${ }^{8}$ Yvonne Yazbeck Haddad and John Esposito., eds. Muslims on the Americanization Path (New York: Oxford University Press, 1998), 34.
} 
which are not in sync with American democratic values and institutions. ${ }^{9}$ Hamid Dabashi built on Said's concept of Orientalism when he stated that imperialism and stereotypes from colonialism did not remain static but evolved. ${ }^{10}$ He discussed this in his book, PostOrientalism: Knowledge and Power in Time of Terror. Like Said, Hamid Dabashi questions the authority of the West in depicting the Orient as traditional, primitive, illiterate and inferior. He recognized that Orientalism continues to reflect more of the West's views on the East or Islam per se. He argued the need to recognize the modes of knowledge production describes Orientalism today. ${ }^{11}$ Knowing who controls what information is shared about someone or a culture through an article or camera lens is important to understanding Orientalism today. Many people are realizing the power behind the modes of knowledge production. ${ }^{12}$ The media in America also employs technology to cover the stories of these violent attacks and usually, the conclusions of these reports vilify Islam.

My position in this study is that as an Islamic sect, Ahmadiyya is not immune to any of these stereotypes that define Islam in the West. I argue that the Ahmadiyya, which is a minority Muslim group, does not only need to confront these perceptions linked to Islam in the USA. As a tradition delegitimized by mainstream Islamic traditions, the Ahmadiyya must also demonstrate on the one hand that it is a legitimate expression of Islam and on the other hand that it does not fit into Orientalists understandings of Islam. Orientalist ideas

\footnotetext{
${ }^{9}$ Todd Green. The Fear of Islam. (Minneapolis: Fortress Press, 2015), 41.

${ }^{10}$ Hamid Dabashi. Post-Orientalism: Knowledge and Power in time of Terror. (New York: Routledge Taylor \& Francis Group), 19.

${ }^{11}$ Hamid Dabashi. Post-Orientalism: Knowledge and Power in time of Terror. (New York: Routledge Taylor \& Francis Group), 22.

12 Ibid, 25.
} 
have functioned as foils against which the Ahmadiyya have always presented positive images ages of itself. The Ahmadiyya has always prided itself on being an Islamic tradition amenable to the modern world and more suited to the West, than any other Islamic form.

Another basic assumption of this study is that the 9/11 terrorist attacks and subsequent acts of violence executed by ISIS and Al Qaeda have entrenched orientalist's notions of Islam deeper into the fabric of American society. More importantly, these activities have added a new image of the religion of Islam to American understandings. Islam became a "dangerous" religion with concepts (such as jihad) and practices that feed a war Muslims have with the West, Western values and Western practices. In support of this position are views about Islam by Hirsi Ali, Shapiro, and Harris on Twitter stating how "Muslims are terrorists and they're a disease. Islam is evil, torture is defensible and whites are genetically smarter than POC (people of color). We should militarily destroy Islam." I argue that this climate has furnished the Ahmadiyya with a new impetus. The community is more determined than ever before to show that although it is a legitimate sect of Islam, its practices and values are more in tune with the West, American values, and practices than Islamic orthodoxies. The Ahmadiyya seeks to demonstrate that it is the kind of Islam that can fit well into American society. A leading figure, Qasim bolstered this position when he noted at one time, "Our Muslim women enjoy more freedoms than many do in the West”, Qasim says. Islam made it possible for many women to choose whom to marry, and to own their own business even before many women in the United States began to have this privilege" $\cdot{ }^{13}$ In the chapters of this study, we will read more about how the Ahmadiyya pushes this agenda using public appearances and engagements and social media platforms

${ }^{13}$ Qasim Rashid. The wrong Kind of Muslim. (United States: AyHa Publishing, 2013), 31. 
such as Twitter, Facebook, and Periscope to speak correctly about Islam, or their brand of Islam. The Ahmadiyya does this to correct the wrong perceptions people have of Jihad and other subjects on Islam, by rendering its own interpretations.

Michael Warner's essay entitled "Publics and Counterpublics," offers a more sophisticated way of understanding the efforts of the Ahmadiyya to produce a discourse that is counter to the public understanding of Islam in the USA. Warner's essay hinges on the description of two terms "Publics" and "Counterpublics." He says that a "Public" is self-organized, and it is a space of discourse organized by discourse. ${ }^{14}$ The interactions occurring in any public space set the tone and boundary of what is shared or communicated. Whenever there is a discourse, the Public is engaged. Warner posits that a Public is also a relation among strangers and that speech can be both personal and impersonal. ${ }^{15}$ A Public is also constituted through attention. It is the social space created by the "reflexive" circulation of discourse. ${ }^{16}$ To clarify this point, any interaction ultimately draws attention to the group. The interaction or the discourse sets the boundary for persons engaged in the discourse. The group giving attention to the ongoing discourse is the Public. The medium through which the Public receives the discourse is the space. The Public comprises a group of people who are generally do not know each other but are invested and interested in the current discourse. ${ }^{17}$ They are in more ways stakeholders of the conversation that is had. It is in this sense that Warner describes the Public as being a relation among strangers.

\footnotetext{
${ }^{14}$ Michael Warner. Publics and Counterpublics. (Brooklyn NY: Zone Books, 2002), 64.

${ }^{15}$ Michael Warner. Publics and Counterpublics. (Brooklyn NY: Zone Books, 2002), 65-68.

${ }^{16}$ Ibid.

${ }^{17}$ Ibid.
} 
Counterpublics, Warner argues, operates in a much similar fashion as the Public. The features that describe the Public also define the Counterpublics. ${ }^{18}$ However, the discourse of the Counter- publics is different and usually opposed to the discourse of the Public. The defining line here is that the Counterpublics is not a subsidiary of the Public. ${ }^{19}$ Even though the groups that constitute them are also vested in the discourse, the Counterpublics are in support of a different narrative that is usually not in agreement with the discourse of the Public. Within an issue of discourse, there is a Public and a Counterpublics. Those who comprise the Counterpublics are also a Public, but they subscribe to a different narrative.

Following Warner's line of thinking I argue that the narrative of Islam in America is predominantly negative. The public rhetoric of Islam associates it with terrorism. After the 9/11 attacks in the United States, many pointed to Islam, identifying it as the root of the atrocity. Even after many years, the negative stereotype of Islam prevails. One can find it in the news media and social platforms in the United States. On news media such as Fox News, CNN, The New York Times among others, and social media platforms like Twitter, YouTube, and Facebook, the narratives about Islam and its links with terrorism and incompatibility with the American culture appeals to a Public that subscribes to such discourse..$^{20}$ These negative views have fed into the government programs and have become part of the present administration's agenda to snuff out Islamic groups in the West because they aid terrorist activities. This is a portion of the discourse on Islamophobia and it has a Public in the United States, in that it draws attention from the American public.

\footnotetext{
${ }^{18}$ Ibid

${ }^{19}$ Ibid.

${ }^{20}$ Todd Green. The Fear of Islam. (Minneapolis: Fortress Press, 2015), 236.
} 
Conversely, there is a Counterpublics that digresses from these narratives and stereotypes of Islam. The Ahmadis, who are the focus of this research offer a context for the propagation of a counter-discourse that subscribes to the notion that Islam is not in any way linked to terrorism and is indeed compatible with American culture and values. This discourse presented by the Ahmadis also has an audience or a Public. The position of the Ahmadis and their Public maintain that many in America have never had any real interactions with a Muslim and are wrongly informed about Islam. ${ }^{21}$ I argue that these narratives by the Ahmadiyya are shared in the same space (news media and social media platforms) that the Public also uses.

My point here is that the Ahmadiyya Muslim Community addresses terrorism related to Islam in America whiles it also deals with issues that discredit it in the Muslim community. The chapters that follow in this study present how the Ahmadis try to own Islam in order to correct the perception of the religion in the American public, particularly in Miami, South Florida, where this study was conducted. I also find how the Ahmadis, through these discourses and activities respond to the traditional forms of Islam, the Sunnis, and Shias, who come against them, arguing that they are not Muslims.

Lastly, to theorize the outreach initiatives of the Ahmadis in South Florida I engage the scholarly perspective that draws on the idea of the religious market as a metaphor in analyzing the behavior of religious communities and their agents in pluralistic religious spaces. This view likens religion to a commodity, and worshippers, to consumers shopping

${ }^{21}$ Qasim Rashid. The Wrong Kind of Muslim. (United States: AyHa Publishing, 2013), 50. 
on markets for spiritual commodities. ${ }^{22}$ The operations of religious leaders as purveyors of various forms of religious capital are analogous to producers and entrepreneurs in a commercial economy, in that their actions represent calculated responses to the strictures and opportunities found on the religious market place or the religious field. ${ }^{23}$ The relative freedom of choice exercised by worshippers motivates religious groups to produce or supply attractive commodities to their clients, advertise and sell their wares and compete with other suppliers to maintain a niche with a steady demand for their supplies. ${ }^{24}$ American society represents a pluralistic religious market place where competition among the various religious groups and agents is very intense. Sharing this market place with other Islamic schools and other religious bodies, the Ahmadis must respond in calculated ways to the structures and opportunities that exist. This study shows how they use their outreach initiatives, sermons, online activities as marketing strategies to present a positive image of themselves in an American religious market place largely informed by Islamophobia. The study is about how the Ahmadis are shaping themselves to the religious market in the USA in an era of Islamophobia.

\footnotetext{
22 Asonzeh Ukah. Advertising God. Nigerian Christian Video Films and the Power of Consumer Culture. (Brill, 2003), 206.

${ }^{23}$ Steve Bruce. Religion and Rational Choice. A Critique of Economic Explanations of Religious Behavior. (New York: Oxford University Press, 1993), 205.

${ }^{24}$ Roland Robertson. The Economization of Religion Reflections on the Promises and Limitations of the Economic Approach. (Social Compass, 1992),157.
} 


\section{CHAPTER III}

\section{FIELDWORK AND METHOD OF DATA COLLECTION}

I obtained data from my fieldwork conducted on the interfaith programs and community outreach initiatives of the Ahmadiyya Jama'at (community). I was also interested in the discourse that the members of the Ahmadiyya Jama'at shared with the Miami community regarding Islam, the meaning of Jihad, tackling Islamophobia etc. I also focused attention on the community's social projects and volunteer programs. I conducted interviews with four leaders of the Ahmadiyya Jama'at in Miami. I also had interviews and informal conversations with lay members of the Ahmadiyya community in my field research. I observed the activities of the community's members and leaders. I studied their preparations for community outreach programs, their interactions with the people participating in the interfaith dialogues, their prayer meetings, and sermons, and their weekly Coffee, Cake and "True Islam" meetings in the Masjid and in public spaces. The Ahmadiyya Jama'at is always on the move. Their activities, which often follow the format used by missions made it necessary for me to be with them for extended periods. Consequently, I conducted the study from Summer and Fall 2017 to the Spring of 2018. In what follows I describe in the setting in which I did the study and how I used the methods earlier mentioned to collect the data that went into the writing of the study. 


\section{The Ahmadiyya Community ANd Geographical Setting}

Baitul Naseer Mosque is situated in South Florida's most budding and bustling county. The Mosque is in Broward County. This is the regional headquarters of the Ahmadiyya in South Florida. The location of Baitul Naseer in Hallandale Beach is not too distant from MiamiDade County. This location enables the Ahmadiyya Muslim Community to serve the African-American and Hispanic communities in these two counties. $208 \mathrm{NW} 7^{\text {th }}$ Court, which is the address of Baitul Naseer is on the outskirts of a residential community. The rather quiet neighborhood contrasts with the busy main street on NW $2^{\text {nd }}$ Avenue. The Mosque is close to small businesses, warehouses, gas stations, chain stores, and a power plant that serves the area. It is also close to a Catholic and a Presbyterian church. The Hallandale neighborhood has a mix of Hispanics and African-Americans, most of whom are members of the Catholic Church. The Presbyterian Church is also composed predominantly of African-Americans and Hispanics. The membership of the Ahmadiyya community, which is a little over 75 peoples pales in comparison with the membership of the Catholic and Presbyterian Churches.

\section{RELIGIOUS LiFE}

The image of South Florida as the destination of a lavish life of endless entertainment is not an exact depiction of the complex interactions that happen daily. South Florida is also a collection of people with deep religious convictions. Sometimes, the religious cultures enable the people in South Florida to be connected to their roots back home. Religious spaces serve are places for people to interact and continue to share common bonds. Each 
day has a dedicated activity for each different religious group and some of the events that add to the lavish and fun image of South Florida are organized by these religious organizations.

The members of the Ahmadiyya Jama'at consider it a sacred duty to attend prayers each Friday as it is an important tenet of the Muslim faith. The prayers are attended by every member of the Jama'at at 1:00 pm in the afternoon. On other days in the week, the Jama'at offers prayers in the afternoons. The sermons delivered on Fridays after the prayers are integral to the faith of the Jama'at. These practices are not exclusive to the Ahmadiyya in South Florida. They are also performed in other parts of the United States. Their sermons convey and remind the Jama'at of the tenets of Islam.

\section{Participant Observation}

I made frequent trips to Hallandale to participate and witness the activities of the Ahmadiyya Jama'at. During these trips, I made efforts to understand the importance of the rituals they performed at the Masjid and the many activities they carried out in the community to combat the negative public perceptions about Islam. The Friday prayers and sermons are an integral part of the Muslim faith and they foster members' belief in the religion. I was always warmly welcomed at the Friday prayers. A member always greeted me personally. It is through such gestures that the Ahmadiyya fosters good relationships with the larger society, and develop cordial links that eventually help it to change negative perceptions about Islam. 
I must mention the efforts of the Ahmadiyya in reaching out to the Christian community in Hallandale as they celebrated Christmas and the New Year. These events formed part of the activities of the Jama'at to show how Islam is compatible with American values and culture and how it is far from the violence that people Associate with it. These events were helpful but the weekly Coffee, Cake and True Islam and interfaith dialogue meetings were consistent ways through which the Ahmadiyya discussed with people about Islam and terrorism in the United States. I recorded many of the observations I made in this study in my field pocket notebook.

\section{INTERVIEWS}

I conducted interviews with the members of the Ahmadiyya during my visits. The interviews were not structured and I did not follow a rigid line of questioning. I presented my interview questions in a way that allowed for casual conversations. Their responses to some of the questions I posed from my list of interview questions and observations informed me of the nature of the activities of the Ahmadiyya. Each activity was tailored to contribute to the community and most importantly to counter the narrative of terrorism related to Islam in the community. I employed similar methods in my interviews during the Miami Book Fair, and the weekly Coffee, Cake, and True Islam meetings.

I also received invitations to hear more from a member called Zafar at the Masjid. I recall making the long journey by train to meet him in Hallandale in the evening. He was willing to share more about his life before becoming an Ahmadiyya and how he became one. He spoke from his desk in one of the offices in the Masjid eagerly recalling the events 
that made him become an Ahmadi. He responded to some of the questions I posed referencing the political climate in the United States and how some of the decisions and policies of the current administration were outright discrimination against Muslims. He answered to the Muslim Ban, the history of the Ahmadiyya and its founder in India, the beginnings of the Jama'at in America and how Baitul Naseer was established. More interviews were conducted when I volunteered with the Ahmadiyya during the Miami Book Fair. Other members of the Jama'at from different states in the US came solely to support the Jama'at Miami during this time. They contributed perspectives and willingly shared information with me. Each event I went to enabled me to gather enough responses for the study and I verified the information I received by asking some questions again but differently and weighed the responses. I also observed keenly what they did and did not do in each event and place they went. 


\section{CHAPTER IV}

\section{LITERATURE REVIEW AND CONTRIBUTION OF THE STUDY}

This study aims at a deeper understanding of the influence of Islamophobia on the discourses and activities of the Ahmadiyya in Miami. To place the study in the ongoing scholarly discourse we must review what has been written about Islamophobia, especially in relation to what it is, how it manifests in societies around the globe, especially the USA, how it affects Muslims, and how Muslims, especially those in the USA, are shaping themselves to this way of looking at them and their religion as they seek to integrate into American society. The aim of the discussion in this chapter is to offer a backdrop to the study by exploring what has been written about the general socio-political environment to which the Ahmadiyya is shaping itself in South Florida. I present an analysis of the Ahmadiyya history and how they are shaping themselves in America in the face of Islamophobia. The literature I discuss in this section highlights themes such as Islamophobia, challenges Muslims face in integrating into Western societies and how some Muslim groups are responding. The debates about Islam and terrorism in the United States and other parts of the West contain these themes.

\section{UNDERSTANDING ISLAMOPHOBIA}

I begin with what scholars such as Fred Halliday and the findings from the Runnymede Trust point to about Islamophobia. Halliday accurately unearths the complexity in the term Islamophobia. The term Islamophobia, according to Halliday, is more anti-Muslim than anti-Islam because it is bigotry against the people rather than the religion. ${ }^{25}$ However,

${ }^{25}$ Fred Halliday. Two Hours that Shook the World. September 11, 2001. Causes and Consequences. (Saqi books, 2002), 224. 
Islamophobia cannot refer alone to anti-Muslim because Islam is part of the belief and practice of Muslims. Any bigotry against Muslims is also tied to hatred against Islam. ${ }^{26}$ 'Islamophobia' is an umbrella term incorporating criminal behavior, open hostility and bigotry, and prejudice aimed at Muslim or Islamic targets. ${ }^{27}$ Shahid Arthar argues that phenomena described as 'Islamophobic' may be described using the more traditional lexicon of racism. In other words, 'Islamophobia' operates in the same way racism does. ${ }^{28}$ This is particularly true where people of actual or assumed ethnic backgrounds are identified (rightly or wrongly) as being Muslim and are, on that basis, made the target of attitudes or actions that are prejudicial. ${ }^{29}$

It may be seen that the concept of 'Islamophobia' captures a wide range of actions and targets. Actions may range from the direct harm or criminal violence to indirect harm caused by the construction of stereotypes. ${ }^{30}$ Targets may include those chosen by the perpetrator based on religion, ethnicity, and culture, or these elements combined. The point here is that there exists a broad ambit under which actions and targets may inform deeds or words which may be individually or collectively described as 'Islamophobic'. The Runnymede Trust report offered one of the few attempts to provide a comprehensive definition of the term 'Islamophobia'. This definition centered on 'closed' views of Islam

\footnotetext{
${ }^{26}$ Jane Smith. Islam in America. (New York: Columbia University Press, 2010), 78.

${ }^{27}$ Todd Green. The Fear of Islam. (Minneapolis: Fortress Press, 2015), 15.

${ }^{28}$ Shahid Arthar. Reflections of an American Muslim. (Chicago: Kazi Publications, 1994), 76.

${ }^{29}$ Jane Smith. Islam in America. (New York: Columbia University Press, 2010), 56.

${ }^{30}$ Yvonne Y. Haddad and John Esposito. Muslims on the Americanization Path (New York: Oxford University Press, 19980, 54.
} 
(which represent Islam as monolithic, static, inferior, and as an enemy) and of Muslims (which represent Muslims as manipulative). ${ }^{31}$

One of the few other notable attempts to provide a theoretical and conceptual framework for the term was made by Chris Allen in a book published in 2010. He asserted that the Runnymede definition is too limited in scope, and therefore in utility. ${ }^{32}$ Allen offered a lengthy definition of 'Islamophobia' as an ideology like, yet distinct from, racism that casts Muslims and Islam as the 'Other' in theological, social, cultural or racist contexts (through implied or explicit means). Allen's definition may be described as having mounted a challenge to the earlier Runnymede Trust definition. The definitions given by the Runnymede report and Chris Allen, Shahid Arthar and Todd Green explain the embedded complexity in the term and helps our understanding of the nature of Islamophobia. Based on these definitions in this study, Islamophobia is a set of attitudes that places Muslims and Islam as the enemy in the West.

The literature also demonstrates the diverse ways in which Islamophobia finds expression in Western societies, especially the USA. As mentioned, Islamophobia is evident when Muslims are perceived as categories that do not belong to (the superior) "us" but are inferior "others". ${ }^{33}$ The notion of $u s$ versus them is therefore integrated in a way whereby the dominant discourse excludes Muslims and Islamic affiliations. That is to say that Islam does not share any of the core values in other religions in the Western culture.

\footnotetext{
${ }^{31}$ The Runnymede Trust. Islamophobia a Challenge for Us All. (London, Runnymede Trust, 1997).

${ }^{32}$ Chris Allen. Islamophobia. (New York: Ashgate Publishing, 2010), 52.

${ }^{33}$ Ibid, 83.
} 
Placing Islam as the "other" indicates that the religion does not have respect for religious diversity and freedom of religion as Christianity does. ${ }^{34}$ In an interview with Julie Hunt, Ulrich Schluer responded, comparing Islam and Christianity, saying that Christianity is an attitude of freedom and embraces tolerance whiles Islam does not. ${ }^{35}$ This view feeds the perception that Islam is inferior and cannot be in sync with Western values of religious freedom and diversity. The point echoes Edward Said's observation that "the general basis of Orientalist thought is an imaginative and yet drastically polarized geography dividing the world into two unequal parts, the larger, 'different' one called the Orient, the other, also known as 'our' world, called the Occident or the West. ${ }^{\text {"36}}$ There are, of course, many religious, psychological, and political reasons for this, but all of these reasons derive from a sense that so far as the West is concerned, Islam represents not only a formidable competitor but also a late coming challenge to Christianity. ${ }^{37}$ A power relation of $u s$, the Occident (or the West), versus them, the Orient, becomes apparent. Some scholars have noted that while Islamophobia is perceived to be a fairly 'new' concept, it has its underlying historical precedents.

\footnotetext{
${ }^{34}$ Todd Green. The Fear of Islam. (Minneapolis: Fortress Press, 2015), 13.

${ }^{35}$ Ulrich Schluer, interviewed by Julie Hunt, Anti-Minaret Campaigner Puts Case. (October 6, 2009). http://www.swissinfo.ch/eng/multimedia/video/Anti-minaret_campaigner_puts_case.html

${ }^{36}$ Edward Said. Covering Islam. How the Media and the Experts Determine How We See the Rest of the World. (London: Vintage Books, 1997), 4-5.

${ }^{37}$ Ibid.
} 
Said, for example, explains however, since the Middle Ages and some part of the Renaissance in Europe, "Islam was believed to be the demonic religion of apostasy, blasphemy, and obscurity". ${ }^{38}$

This sheds light on how the Orient has stood in a negative contrast to the ChristianWest through many centuries to this day. The sense here is that visions of the different and exotic triggered connotations have been altered today and therefore give life to Islamophobia.

Another theme in the discourse on Islamophobia is the idea that Muslims use their religion for strategic, political and military advantage rather than as a religious faith and as a way of life shaped by a comprehensive legal tradition. Muslims are assumed to have an instrumental or manipulative view of their religion rather than being seen as people who are sincere in their beliefs. The idea here is that many in the West see the Islamic faith as "indistinguishable from a weapon". ${ }^{39}$

Drawing on such positions, the Runnymede Trust, Ouis, and Roald emphasize how one aspect of Islamophobia is the notion that Islam is a violent religion. ${ }^{40}$ Francis Fukuyama also notes how popular opinion views Islam as a backward religion, resistant to change and repelling modernity. He notes how people see modernism as characterized by the practice of liberal democracy, capitalism as well as feminism, and for Fukuyama, and

\footnotetext{
${ }^{38}$ Ibid, 5.

${ }^{39}$ The Runnymede Trust. Islamophobia a Challenge for Us All. (London, Runnymede Trust, 1997).

${ }^{40}$ Ouis and Roald. Muslim in Sweden. (Stockholm: Wahlström \&Wikstrand, 2003), 28.
} 
Scheffer, Islam does not encourage these modern principles and ideologies. ${ }^{41}$ Aaron Hughes and Jane Smith state that this perception may be based upon the tendency to generalize religious interpretations of some specific terrorist groups across the whole Muslim community and Islam. ${ }^{42}$ They point out how these views eventually lead to the practice of perceiving every single (Muslim) act as a generalization for everyone else in the tradition. ${ }^{43}$ The problem, they argue, is that Muslims are seen as one (religious or cultural) identity rather than a multitude of identities. They argue that to see Muslims as a homogeneous group contributes to concealing individual Muslims and other attributes such as nationality, ethnicity, class, and gender. Ayaan Hirsi Ali has a different view about Islam from what Aaron Hughes states. Hirsi Ali also submits that Islam is inferior and represses women in the religion. According to her, Islam is barbaric, sexist, irrational, and in contrast to the civilized, enlightened and gender-equal West. ${ }^{44}$ Hirsi Ali argues that Islam's practice of subjugating women is one of the things that makes it so reprehensible and anti-Western. She does not believe that Islam has anything to offer the West because it lags behind the West intellectually, culturally and ethnically. ${ }^{45}$ We will see in this study how the Ahmadis in South Florida are responding to this situation through their discourse and outreach initiatives.

\footnotetext{
${ }^{41}$ Aaron Hughes. Muslim Identities. An Introduction to Islam. (New York: Columbia University Press, 2013), 35.

${ }^{42}$ Ouis and Roald. Muslim in Sweden. (Stockholm: Wahlström \&Wikstrand, 2003), 36.

${ }^{43}$ Ibid.

${ }^{44}$ Ayaan Hirsi Ali, Chahla Chafiq, Caroline Fourest et al., Together Facing the New Totalitarianism. BBC News (UK). (March 1, 2006). http://news.bbc.co.uk/2/hi/europe/4764730.stm.

${ }^{45}$ Ibid.
} 
Some researchers have written about the consequences of such thinking, especially how it negatively impacts the successful integration of Muslims into Western societies.

Samuel Huntington in his book, "The Clash of Civilizations" demonstrates how the notion that Islam is incongruous with the American way of life makes it difficult for Muslims to assimilate well in America. ${ }^{46} \mathrm{He}$ notes how cartoon characters and caricatures are used to depict the state of the Muslim who is secretly plotting to do harm. ${ }^{47}$ Todd Green writes about the growing public sense that the Muslim is secretly planning to overtake American government with Shari'a. ${ }^{48} \mathrm{He}$ notes how many people in the USA believe that the Muslim creates his own community and way of doing things that do not line up with the host communities they are in. He also notes how these perceptions and narratives feed into the discourse about Islam as anti-modern and incompatible with American values. Scholars such as Paul Scheffer who side with this view maintain that Muslim integration into the American way of life is impossible and will only to lead to more terrorism in the country.

Jane Smith, Todd Green and Gilles Kipel focus on how Muslims are voicing out their concerns about the treatment they have received based on the stereotypes and assumptions against them in Western nations. In a recent Pew Research Survey in 2017, half of Muslims in America stated that they had experienced some form of discriminatory behavior against them based on their religion. A third of Muslims from the study also confirmed the suspicions they experienced for being Muslim. ${ }^{49}$ Muslims describe how they have

\footnotetext{
${ }^{46}$ Samuel Huntington. The Clash of Civilizations. (New York: Touchstone, 1997), 210-212.

${ }^{47}$ Ibid.

${ }^{48}$ Todd Green. The Fear of Islam. (Minneapolis: Fortress Press, 2015), 43.

${ }^{49}$ Pew Research Center. How the U.S General Public Views Muslims and Islam. July 26, 2017.
} 
experienced these situations at security checkpoints in airports, and in some public spaces such as transits and malls. They have been addressed with offensive comments. Many Muslims have also experienced offensive anti-Muslim graffiti on their Mosques and in their local communities. This has been prevalent even among those whose appearance suggest to others that they are Muslim. ${ }^{50}$ Others have been maimed and killed and some attacks are also extended to their Masjids where they usually meet for religious activities. ${ }^{51}$ These ideas of incompatibility sometimes translate into attacks on Muslims in the United States, especially after 9/11. The depictions above point to how Islamophobia manifests as racism and hatred towards the religion. Debates about whether Islamophobia falls under racism continues among scholars. Nasar Meer and Tariq Modood argue that people do not choose to be born into a Muslim family, nor do they choose to be born into a society in which to be Muslim or to have ethnic roots in a Muslim majority country, but this automatically makes one an object of suspicion among the non-Muslim majority population. ${ }^{52}$ Robert Kilroy-Silk, a former British politician, expresses his views about Arab countries as anything but civilized. He labels all Arabs as suicide bombers, limb amputators and women oppressors. ${ }^{53}$ This fosters the negative stereotype about Muslims and the assertion made by Nasar Meer and Tariq that Islamophobia is linked to racism.

\footnotetext{
${ }^{50}$ Todd Green. The Fear of Islam. (Minneapolis: Fortress Press, 2015), 35.

${ }^{51}$ Ibid.

${ }^{52}$ Nasar Meer and Tariq Modood. Refutations of Racism in the Muslim Question. Patterns of Prejudice. (Routledge, 2009), 345.

${ }^{53}$ Quoted in Ali Rattansi. Racism. A Very Short Introduction. (Oxford University Press, 2007), 110.
} 
Another facet of the argument that is often made in the Islamophobia literature deals with the failure of Muslims to fit well into multicultural Western societies. Research that argues against the integration of Islam in America often cite examples of the failure of attempts to integrate Muslims in European countries and in Australia. Local clashes between residents and Muslims, violent attacks on the public by Islamist extremists are often cited as clear indications of the danger of allowing Islam to become a part of the American way of life.$^{54}$ This also feeds into the backlash against Muslim immigrants in the USA. Residents of European countries and Americans also point to the various attacks that occurred destroying lives and properties. The Madrid bombings in 2004, the London bombings in 2005, 9/11 in America and other violent attacks in Europe and America have increased tensions between Muslims and non-Muslims. ${ }^{55}$ The increased settlement of Muslims immigrants in Europe and America caused concern about multiculturism in these countries. ${ }^{56}$ Ayaan Hirsi Ali, a critic of Islam, points out that Islam's presence in these countries poses a threat to the freedoms of these countries. Islam poses this threat because it is not compatible with liberal democracy and freedom in the West. ${ }^{57}$ The fact that these attacks were carried out by Muslim extremists exacerbated the hatred for Muslims and Islam in the West. ${ }^{58}$ Muslims have faced difficulty presenting themselves rightly in the

\footnotetext{
${ }^{54}$ Akbar Ahmed. Journey into America. The Challenge of Islam. (Washington DC: Brookings Publications), 43.

55 Todd Green. The Fear of Islam. (Minneapolis: Fortress Press, 2015), 153.

${ }^{56}$ State Multiculturism Has Failed, says David Cameron. BBC News, UK. (February 5, 2011). http://www.bbc.co.uk/news/uk-politics-12371994.

${ }^{57}$ Ayaan Hirsi Ali. Infidel. (New York: Free Press, 2008), 170.

${ }^{58}$ Matti Bunzl. Anti-Semitism and Islamophobia. Hatreds old and New in Europe. (Chicago: Prickly Paradigm Press, 2007), 44.
} 
wake of these attacks that have occurred. However, Muslims continue to counter these arguments about Islam as a violent religion. The next part in this chapter reviews the literature that show what Muslims are doing against the negative stereotypes about them and Islam.

\section{THE RESPONSE TO ISLAMOPHOBIA}

The works and writings of Daniel Pipes, Richard Spencer and Pamela Geller after 9/11 contributed much to the negative image about Muslims and Islam in the American public. Daniel Pipes was successful at justifying the reason to fear Muslims. He is the figurehead of professional Islamophobia in America and disbands the use of the term, Islamophobia. ${ }^{59}$ He asserts that because Muslims pose a threat to everyone else, the Western fear of Muslims is justified. ${ }^{60}$ Spencer and Geller have also fostered the negative stereotypes of violence and terrorism that is prevalent in the American media about Islam. ${ }^{61}$

Some scholars such as Gilles Kipel have a different take on the connection between Islam and terrorism. Gilles Kipel argues that contrary to these arguments and narratives, terrorism in many European countries and the West happens because of a defective system of integration. The West, he argues cannot continue to involve the participation of minority populations and continue to marginalize them; this fuels resentment. In the struggle against terrorism in the United States, Muslims cannot be left on the fringe, and they cannot be blamed. The efforts against Islamophobia and terrorism attributed to Muslims is complex

\footnotetext{
59 Todd Green. The Fear of Islam. (Minneapolis: Fortress Press, 2015),

${ }^{60}$ Daniel Pipes. Militant Islam Reaches America. (New York: Norton, 2002), 53.

${ }^{61}$ Robert Spencer. Islam Unveiled. Disturbing Questions about the World's Fastest-Growing Faith. (San Francisco: Encounter Books, 2003), 37.
} 
and requires various approaches to dealing with the problem. ${ }^{62}$ They are also a part of this struggle since the violence that occurs is always associated with the religion. ${ }^{63}$

A part of the research focuses on how some Muslims are demonstrating resilience in the face of such negative attitudes. Jane Smith argued despite the threat to their lives and families through the racial slurs they face and the attacks on them in their Mosques, some Muslims choose to show their practice publicly now. ${ }^{64}$ They do this by having prayers sometimes in public spaces, through their dress, speech and public commitment. Smith notes that they see it as important to stand up at a time when the religion that also forms a part of their identity is repressed. Previously, many Muslims did not involve themselves in the public or political activities in the United States. This has changed, according to Smith. More Muslims have become more interested in what happens in the political space in America after 9/11. In other facets of public life, Muslims have gained positions of importance that help them to propagate the idea that Islam agrees with the American way of life. Muslims in these various positions are also overt about their practice, usually joining their local Mosques for prayers and participating in public activities that serve their communities. ${ }^{65}$

Smith also unearths difficulties that beset Islamic groups and agents that seek to combat the negative popular images of their religion in the USA. One difficulty concerns the question of leadership and organization. Smith argues that because Islam is diverse in

\footnotetext{
62 Juan Cole. Engaging the Muslim World. (New York: Palgrave Macmillan, 2009), 43.

${ }^{63}$ Deepa Kumar. Islamophobia and the politics of Empire. (Chicago: Haymarket, 2012), 59.

${ }^{64}$ Jocelyne Cesari. Muslims in the West After 9/11. (New York: Routledge, 2010), 32.

${ }^{65}$ Jane Smith. Islam in America. (New York: Columbia University Press, 2010), 114.
} 
culture, ethnicity, and practice it is difficult to cast all Muslims as one group. ${ }^{66}$ There are many differences, and often these lead to disagreements among agents and followers. The question of whose voice represents Islam in the USA is a highly contested one within the Muslim community.

Islam is not a homogeneous tradition. ${ }^{67}$ Different Islamic schools respond differently to situations. Yet, the question of how specific sects or schools within the tradition are responding to the present Islamophobic socio-political milieu in the USA represents one hiatus in the ongoing academic discourse. My motivation for focusing on the Ahmadiyya in this study is driven by my quest to contribute to filling this crucial gap. The Ahmadiyya Muslim Community is among the many Muslim communities countering Islamophobia in America, and the following literature in this part discusses the history of the Jama'at and its beginnings in America.

\section{Ahmadiyya in America}

The largest ethnic Muslim group in America is from South Asia, which includes Pakistanis, Indians, and people from Bangladesh. ${ }^{68}$ This is where majority of the Ahmadiyya membership comes from. Founded by Mirza Ghulam Ahmad in India in 1889, the Ahmadiyya Muslim Community began as an offshoot from the Sunni branch of Islam. One of their main objectives is to bring a revival and establishment of the glory of Islam through

\footnotetext{
66 Ibid.

${ }^{67}$ Gerd Baumann. The Multicultural Riddle. Rethinking National, Ethnic and Religious Identities. (London: Routledge, 1999), 44.

${ }^{68}$ Simon Ross Valentine. Islam and the Ahmadiyya Jama'at. (New York: Columbia University Press, 2008), 34 .
} 
their Promised Messiah and founder, Mirza Ghulam Ahmad. ${ }^{69}$ Their belief in a prophet after Muhammed places them under heavy persecution from other Muslim groups in Pakistan, Indonesia and other Muslim majority countries. ${ }^{70}$

The Ahmadiyya is a missionary group and has established its presence in Europe, Africa and the Americas. The Ahmadiyya Muslim Community emphasizes the nonviolent aspect of jihad. Following the death of the founder, Mirza Ghulam Ahmad in 1908, the Ahmadiyya community split into two groups - the Qadian and Lahore groups. ${ }^{71}$ The Lahore group established its headquarters in Pakistan, but after much persecution in Pakistan, the headquarters of the Ahmadiyya community was moved to London where it remains the headquarters of the Ahmadiyya Community. ${ }^{72}$ Ahmadis also experience Islamophobia in Europe. Islamophobia in Europe has also followed violent attacks that were carried out by Muslim extremists. ${ }^{73}$ The attack on London and Paris added to the Islamophobic sentiments already present in Europe. The Ahmadiyya community responded to these attacks by condemning the violent acts done in these places. ${ }^{74} \mathrm{By}$ emphasizing nonviolent jihad, which is jihad by the pen, the Ahmadiyya educates the public in Europe through various community engagements that bring the public to

\footnotetext{
${ }^{69}$ Aaron Hughes. Muslim Identities. An Introduction to Islam. (New York: Oxford University Press, 1998), 88.

${ }^{70}$ Simon Ross Valentine. Islam and the Ahmadiyya Jama'at. (New York: Columbia University Press, 2008), 39.

71 Ibid.

72 Ibid, 42.

${ }^{73}$ Jocelyne Cesari. Muslims in the West After 9/11. (New York: Routledge, 2010), 37.

${ }^{74}$ Anne Michaud. Muslim Community responds to Paris Attacks. January 16, 2015.
} 
understand Islam and Ahmadi Muslims. ${ }^{75}$ The growth of the Ahmadiyya Muslim Community has also been experienced in America.

The first Ahmadi mission to America was in 1920 by Mufti Muhammed. ${ }^{76}$ Fleeing persecution in South Asia, the Ahmadis established their first Mosque in Chicago. The Ahmadiyya Jama'at later moved its headquarters to Silver Springs, Washington, DC. ${ }^{77}$ As a missionary group, they have adapted their positive brand of Islam to counter the stereotypes that exists about Islam due to terrorism and a fear of Islam in America perpetrated in the American public. ${ }^{78}$

The Ahmadiyya Jama'at counters Islamophobia mainly through educating the American public about Islam. They meet with members of congress in America given the good positioning of their headquarters in Washington, DC to influence policies against Islam. The Jama'at also engages with the American public through its various community engagements to show Islam positively devoid of violence. ${ }^{79}$ The missionary nature of the Ahmadiyya has enabled the Jama'at to establish more mosques in almost every state in America. Countering Islamophobia through its missions in these states in America is now part of their community programs which they have with the public.

\footnotetext{
${ }^{75}$ John Hanson. Jihad and the Ahmadiyya Muslim Community. Nonviolent Efforts to Promote Islam in the Contemporary World. The Journal of Alternative and Emergent Religions. Vol 11. No. 2. November 2007.

${ }^{76}$ Jane Smith. Islam in America. (New York: Columbia University Press), 71.

77 Ibid.

${ }^{78}$ Simon Ross Valentine. Islam and the Ahmadiyya Jama'at. (New York: Columbia University Press, 2008), 43.

${ }^{79}$ Simon Ross Valentine. Islam and the Ahmadiyya Jama'at. (New York: Columbia University Press, 2008), 47.
} 
The Ahmadiyya is mainly self-financed, receiving contributions from its members to fund its activities. They have successfully erected health institutions, and schools for the communities they find themselves in. The Ahmadiyya Muslim Community also has their own television network that broadcasts their programs worldwide. With four channels dedicated to educating and inspiring the Jama'at, the Muslim Television Ahmadiyya (MTA) is there to broadcast the message of "true Islam". ${ }^{80}$ This outreach forms part of the various ways Ahmadiyya counters the narrative of Islamophobia in the American public.

As a point of departure, I draw attention to the emerging trend of organized response by the Ahmadiyya to Islamophobia in America. This study also shows how Ahmadiyya differs from traditional forms of Islam and how it fosters social and religious cohesion through their interfaith meetings with those of other faiths against Islamophobia.

${ }^{80}$ Ibid. 


\section{CHAPTER V}

\section{AHMADIYYA IN MIAMI - THE PHYSICAL TEMPLE, THE COMMUNITY AND ITS HISTORY}

The Ahmadiyya Jama'at is one of the many sects of Islam. Mirza Ghulam Ahmad founded the Ahmadiyya Muslim Community in India in $1889 .{ }^{81}$ The Ahmadis consider themselves as nothing less than "the true Islam" although this claim is vehemently contested by Muslim groups that consider themselves to be orthodox. The Ahmadis also present themselves as the most dynamic subgroup of Islam and claim to demonstrate the religion in its purest form ${ }^{82}$ Their objective, they claim, is to establish the relationship of love between Allah and his servants and promote unity between different sections of mankind. The community also claims that one of its objectives is to revive Islam, purge it of its negative traits, and establish its glory. ${ }^{83}$ The Ahmadis regard themselves as the group charged with the responsibility of restoring Islam's moral and spiritual values. One way they seek to achieve this goal is by abolishing all barriers to human interaction that are based on race and color, so that people may unite and promote universal peace. They believe that this unity will be achieved when everyone embraces the Ahmadi doctrine.

Beginning in India and later extending into Pakistan, the Ahmadi brand of Islam has come under heavy scrutiny and persecution from Islamic groups that consider themselves to be mainstream. In regions of the world where Islam dominates the religious field,

\footnotetext{
${ }^{81}$ Yvonne Yazbeck Haddad and John Esposito., eds. Muslims on the Americanization Path (New York: Oxford University Press, 1998), 88.

${ }^{82}$ Aaron Hughes. Muslim Identities. An Introduction to Islam. (New York: Columbia University Press, 2013), 92.

${ }^{83}$ Yvonne Yazbeck Haddad and John Esposito., eds. Muslims on the Americanization Path (New York: Oxford University Press, 1998), 90.
} 
Ahmadis are delegitimized. They tend to thrive better in those parts of the globe not dominated by Islam but are rather pluralistic. In the discussion that follows, I describe the nature of the Jama' at in Hallandale, the Masjid and offer a brief history of the Ahmadiyya's presence in South Florida.

\section{The Baitul NaSeer MASJID}

The Baitul Naseer Masjid is the headquarters of the Ahmadiyya in South Florida. Situated in Hallandale, Broward County, the Baitul Naseer serves over 80 members of the Jama'at. The name, "Baitul", is Arabic for "House". Naseer also means "Helper" or "Help" in Arabic. The Masjid at Hallandale roughly translates as "House of the Help". The name of the Mosque describes the purpose of the Ahmadiyya and its activities. Ahmadis claim they exist to help fight against the misunderstanding of Islam through their discourse, outreach initiatives, and volunteer programs.

Viewing it from the outside, the Baitul Naseer Mosque has none of the usual features

of a mosque. The building stands among other church buildings in the community and looks more like a Christian church than a Mosque. Members of the community explained how they bought a church when they were denied a permit to build a mosque. The community renovated the interior of the church to accommodate members' needs as Muslims. Thus, the Baitul Naseer Mosque's Islamic identity is evident only when one enters the building. Mudathir shared with me about how the Baitul Naseer building was acquired in an interview with him in Hallandale:

We came here a long time ago about 25 years ago. We were a small community compared to the numbers we have now. People kept coming and joining our Jama'at over time. We wanted a mosque but we couldn't build one immediately. It was easier to purchase 
the building than build the Mosque. We had one experience with our Mosque in Washington. We got the permit from the government but we did not get the nod from the community to build. We ended up buying the Mosque there and that is what we did here too. We did not want to go through that again. We got this building. It was a church and now we converted it to suit us. You can see on the outside, the door, and the foyer. That is still maintained but when you enter the hall, you can see how we have made it suit what we want for our Mosque. Getting this building for our Mosque has helped us to serve our members when they come here to pray. The community also now knows us. When we come out to interact with them, some welcome us and a few have been here in the Mosque during our programs. ${ }^{84}$

The presence of the Masjid among churches in the community also indicates the readiness of the Ahmadiyya to work together with people from other religious faiths.

The Mosques also houses the Imam, the secretary, the outreach secretary, and a few of the members of the Jama'at. Temporary residence is also provided for guests who visit the Mosque. Many of these are members of the Ahmadiyya Jama'at from other states in the United States or other countries who visit and participate in sermons, prayers, and events that are done in South Florida. The Ahmadiyya Jama'at endeavors to make its presence and influence felt beyond Hallandale through its activities.

${ }^{84}$ Interview with Mudathir at Baitul Naseer Mosque Hallandale. 11/14/2017. 


\section{The COMMUnity AND ITS HISTORY}

The Jama'at in Hallandale maintains close ties with other Ahmadi communities across the United States. It also maintains connections with the global headquarters of the Ahmadiyya in London. At the Miami Book Fair, Nazir, one of the leaders of the Jama'at responded to the beginning of Ahmadiyya and their Khalifa saying, the fifth Khalifa of the Jama'at worldwide, Mirza Masroor Ahmad, heads the Ahmadiyya Jama'at. After escaping the violence against the Ahmadis in Pakistan, Mirza Masroor Ahmad went to Ghana where he received extensive education and training. Ahmad found fortune after he successfully cultivated millet, which later became a staple crop in the Northern part of Ghana. Nazir continued that many people had faced difficulty in cultivating crops successfully in Northern Ghana because of its aridity and poor soil. The local population in Northern Ghana, therefore, attributed Mirza Masroor Ahmad's success to the magico-religious powers of his Ahmadiyya religion. This is a key factor explaining the phenomenal success of the Ahmadiyya in Ghana. After a few more years in Ghana, Ahmad left for Europe. As Khalifa, Mirza Masroor Ahmad is the spiritual and administrative head of the Ahmadiyya Muslim Community all over the world.

The Ahmadiyya Jama'at was established in the United States in 1921 during the period of the first Khalifa and founder of the community, Mirza Ghulam Ahmad. Since its establishment in the USA, the Ahmadiyya community has expanded and is currently represented by the many Masjids that can be found across the United States. Although as a community, the Ahmadiyya has been in South Florida for 30 years, the Baitul Naseer Mosque in Hallandale has been in existence for 25 years. It has a little over 86 active members. The Imam and a few leaders and members reside in rooms on the compound of 
the Mosque. Other members live either close by, or in far-flung communities in South Florida. However, most members make a point of showing up for almost every event that is held by the Masjid.

I noticed a keen sense of commitment to the community's causes among members of the Mosque. Each member is assigned a role to play in the events that are held in the Mosque. During my fieldwork, I witnessed one of the younger members leading the "Adan" (call to prayer) on Friday, November 3rd, 2018. Standing behind the pulpit, his hands raised halfway, and touching the tips of his ears, he sang out the call in Arabic. During the Miami Book Fair on November 17th, 2018, some members of the Jama'at and Imam Chaudry busily distributed books at the fair booth assigned to the community. During a blood donation exercise in Fort Lauderdale, the Jama'at came together to pray after they had donated blood that morning. On January 15th, 2018, the Ahmadiyya Jama'at came together to participate in a march honoring Martin Luther King Day. The community's involvement in all these public activities speaks largely to one of their agendas - to demonstrate that they are a different form of Islam, one that is as American as any other religion and that they are willing to be a part of any and everything American. 


\section{CHAPTER VI}

\section{THE DISCOURSE AND ACTIVITIES OF THE AHMADIYYA IN MIAMI}

The Ahmadiyya Community engages in various interfaith meetings, outreaches and volunteer efforts as a means of educating the American public about Islam and countering Islamophobia. The community has been vocal against the 9/11 violent attack in America, the recent Parkland school shooting in Florida, the riots in Charlottesville, Virginia, Mosque bombing in Oregon, and the train bombing in Manhattan, New York. These are violent attacks, some, related to Islamic terrorists, others, not, that the Ahmadiyya have clearly spoken against. In this part of the study, I present data from the fieldwork that highlight the discourses of the Ahmadiyya against this violence in America. I also write about the activities the community carries out as practical ways of demonstrating its brand of Islam as one that is in tune with American values and practices. The point of the discussion is to show how the Ahmadiyya sees the distancing of itself from forms of violence as a way of demonstrating to the American public how its brand of Islam emphasizes peace and progress. This is part of the movement's efforts to purge meanings of Islam in America characterized by orientalist trappings. The Ahmadiyya Jama'at does not limit its focus on violence to incidents that take place only in Florida. It addresses the violence happening in other parts of America too. It also uses online social media platforms to respond to violence related to Islam in other parts of the world. 


\section{Hearing Imam Haneef Speak to the FIU PUblic}

I stuffed the last of my books into my bag. My class for the day was over, and I could quickly rush to use the restroom before going to listen to the Vice-president of the Ahmadiyya Jama'at in the United States speak at Florida International University (FIU). I had barely eight minutes to walk (or run) two blocks to get to the University library, the venue of the program. The Vice president started the talk with the following words:

This is a time in the world where we see a lot of conflict in the world than we see peace. And... a lot of the narrative we hear from our nation and around the world is ... the main source of this war is those of faith. Particularly of the Islamic faith. This is the narrative that myself and others like me and those around have not been pushing back against so to speak, but speaking out against to make sure we have a correct view of what is faith and what is the practice of a people or the responses of a cultural group, social group.

The vice president had been invited to address students at FIU on a topic of his choice. The

fact that he chose to talk about peace pointed to the community's agenda of dispelling the myths floating about Islam being a violent religion. No venue would be better to address such a topic than a university campus with a younger generation of Americans curious to learn new things and very impressionable. He continued:

All those who are here..., who has ever entered the Mosque?" (he looked around the room). A voice echoed, 'zero', and was greeted with laughter. "How many Americans have seen or been with a Muslim", He continued. If this survey were to be conducted in the nation, it will turn out that hardly many Americans have ever been to a Mosque or have had any interaction with a Muslim. Irrespective of what we hear on news. We've heard a lot of conversations about who a Muslim is or what they believe, and what they practice... but how many of us have really stepped back to ask, do I really know a Muslim, and can I judge the faith based on this knowledge? Do you realize it is still less than fifty percent of us? Less than half our nation has 
ever met someone who belongs to our faith. And, even less than that have entered a place where Muslims worship.

To set the stage for his message the vice president was reminding his audience of how little the American public knows facts about Islam. Then, he continued:

Last year there was a rally in Arizona. It was outside a Mosque on a Friday, the holiest day of the Muslim week. The crowd screamed 'we're not gonna let Muslims in our nation and have them prevent our fundamental liberties, such as the freedom of expression'. Before this there was a public event called 'the draw Muhammed cartoon event'. The sense was that it was a right as an Americans for people to express themselves. No one should stop that. Two men drew guns, to protect the crowd. Amongst them there was one young man who was more vocal than everybody else, shouting 'down to the Muslims' and stuff...Finally, when he came close to the Mosque someone said, 'excuse me, have you ever been inside the Mosque? Do you know what Islam stands for? Do you know what we believe'? And he said 'no'. 'He said please come inside. We're about to have our service, come join us'. And the young man took them on their offer and he said, 'for the first time in my life, I went inside a Mosque. I sat down, and I was surprised at what I saw. I saw peaceful people, level-headed... rational. The beliefs also made common sense - belief in God, and ... belief in Angels, belief in Judgement and all these things... right from my own traditions. Then he had the greatest realization that, 'I was wrong. I was discriminating against a group of people I knew nothing about'. And so that next day, he said, 'I wrote in my blog that, I apologize to the Muslim community because I was condemning a group I knew nothing about. I was your greatest enemy...From this day forward, I am your greatest ally. And I will try my best to educate my people, the American people about who you are'. ${ }^{85}$

\footnotetext{
${ }^{85}$ Imam Haneef Speaking in Florida International University. 10/31/2017.
} 
Imam Haneef continued by stating that there was the need to separate faith from politics. He pointed to history, highlighting the various wars that had been fought because people had religion mixed with politics. He alluded to the fact that rebellion and divisions in many religions brought about wars. He said it was not surprising that Islam in this period was also experiencing some of these internal conflicts. Imam Haneef explained that this condition speaks to the times that the Prophet Muhammed predicated a long time ago where Islam in all its glory will lack guidance. He stated also that the solution to the crisis is to continually educate people about what Islam is and to promote the beliefs and practices that will bring a change in perception among people. He also pointed to the public that the Ahmadiyya community led by the founder and the current Khalifa, Mirza Masroor Ahmad is in a position to help bring about that guidance society needs.

Imam Haneef's opening remark and illustration reminded me of an earlier event held on the Florida International University campus in October 2017. It was an event hosted by the School of International and Public Affairs. Reza Aslan, a religious scholar, and author came to speak about confronting Islamophobia by overcoming fear. In the same vein as the Imam, Reza underscored the American lack of familiarity with Muslims and Islam. He pointed out that many Americans rely on the accounts in the news about Islam, news which linked Islam with terrorism and violence. He submitted that Muslim acts of terror are not as prevalent as many Americans are led to believe from media sources. Aslan said, between 2011 and 2015, the Department of Homeland Security and FBI categorized 89 terrorist attacks. Only 11 were perpetrated by Muslims. Non-Muslims were responsible for the rest. Eighteen of the 89 attacks targeted Muslims. However, the press coverage is heavily 
centered on those perpetrated by Muslims linked to terrorist groups. This helps to promote the wrong perception and ideas about Islam, he argued. He mentioned that it is important to forge relationships and get to know Muslims more. This is the first step in defeating the negative perceptions that link Islam with violence and terrorism, he argued. This line of thinking resonates with the Ahmadiyya rhetoric.

\section{MIAMI BOOK FAIR}

Public events such as book fairs offer the Ahmadiyya opportunities to "sell" their brand of Islam to the public. At one such book fairs held in Miami, the community had many books from the Mosque on display. They had wristbands, gift bags, t-shirts, and pens, that had the words "Love for All, Hatred for None" printed on them. These words were also written on fliers and banners. These words reflect the image the community sought to portray in public - an Islamic tradition that promotes love and peace and is open to all members of larger society in the USA.

The Ahmadiyya were granted two additional booths that catered to the needs of the PAAMA (Pan-African Ahmadiyya Muslim Association), and the women of the Ahmadiyya Jama'at. Soon, the path between the booths filled up with people. Many tourists filled the booths. The tall buildings of Downtown towered over the booths and spared us from the sun's heat. Many schools had children come in for the Fair, and they walked away with some wristbands, pens, and gift bags. This will be for many an initial encounter with the Ahmadiyya Muslim Community through the items they would receive. In a move that demonstrates how the Ahmadiyya often takes advantage of such gatherings to re-educate the public on the nature of Islam, a member started into a discourse, addressed the large gathering: 
You may hear of those who may be doing this bad thing or the other. Killing here and there and all that you hear in the news. They are not guided. You see our banner here. It says, 'Love for all, Hatred for none'. Anyone who is doing all these things you hear in the news is not practicing Islam the Ahmadiyya way. Prophet Muhammed spoke about a Messiah who will come after 1400 years to revive the religion. Mirza Ghulam Ahmad, we believe is the Messiah that came. The evidence is there to see. The Ahmadiyya can't be stopped because this is not something ordained by man. It was started by God and our agenda 'Love for all, Hatred for none' is a divinely ordained one" This is the kind of Islam we need for this age. ${ }^{86}$

I stood over the section of the books written in Spanish and faced Mudathir, a Nigerian, who had been in the Jama'at in Miami for five years. "How is it for you each time you do this?" I asked. This prompted him to present a brief lecture on the true meaning of jihad, as the Ahmadiyya community understood it, departing radically from the popular imagination of a jihad as a war that unleashed violence on non-Muslims or Muslims who did not subscribe to specific viewpoints. In the process he introduced the public to a meaning of jihad, he felt, would be more in tune with American values. He raised his voice while speaking, making a point of drawing the attention of the crowd to what he was saying.

Ah me! As for me, this is Jihad for me. This is my Jihad. Eh, promised Messiah explains to us to strive in the cause of Allah...the time we had our big event, errrh... the Jalsa. Do you know of the Jalsa? It is our big event with our Khalifa in London. Many in the Jama'at all over the world come. They come from wherever. Over there, our Khalifa tells us to do our utmost best to be examples where we are. He reminds us that Jihad is not about fighting. It's about striving... to do your best in serving Allah. As I'm here, I had to make it all the way from my place to arrive here to do this. It is part of the striving. The striving shows you're submitting to Allah. You're following the path of peace. It is not picking up guns to fight. Look at you! I heard you also traveled a long distance to get here. Where you stay is far,

${ }^{86}$ Interview with Zafar in Miami Book Fair. 11/17/2017 
but because you love to be here, you came. That is part of the striving I'm talking of". 87

Nazir and Siddiqui came over to listen. Mudathir found the page he was looking for. He drew it closer and pointed to the ending verse.

Errrh, uh huh! This is the chapter 61 in the Quran. It says here... strive in the cause of Allah with your wealth and possessions and efforts also'. You see it there? When you go over from the beginning, it talks about many things related to Jihad, but it does not mention, you, take weapons and fight. That's not Jihad. That's not true Islam. The teachings of our Khalifa and the promised Messiah will guide you not to do this. Now when you see the news, Muslims are fighting all over. You hear one attack here, they say it's a Muslim. Those who say they are Muslims, they even attack us. Why? Because we believe in what the prophet said about the coming Messiah, they say we're not Muslims. But today, look! We are doing this event and they are nowhere to be found. We're teaching and showing what Islam is but they... they are not here. If they are Muslims, they will also be here to talk about what is going on. You see! When I came in, they said gate fee, \$8. Because promised Messiah and Khalifa say, we should give what is due anyone, I paid my fee. You see. That is also part of the Jihad. It began with $\$ 8$, but the blessings of Allah that we expect... Khalifa says many blessings follow the people who strive in the cause of Allah. This is what we're doing. The people here have come to know Ahmadiyya. They know. We're in their communities many times. That is Jihad. I've talked long eh, I know". ${ }^{88}$.

Different Islamic schools have different understandings of the concept of jihad in which there is no link between the word and physical violence. Thus, the Ahmadis share this understanding of Jihad which distances it from violence with other sects of Islam. Mudathir, however, links this interpretation of jihad which stresses its nonviolent nature

\footnotetext{
${ }^{87}$ Interview with Mudathir in Miami Book Fair. 11/18/2017

${ }^{88}$ Interview with Mudathir in Miami Book Fair. 11/18/2017.
} 
with the Ahmadis, claiming, albeit tacitly, that it is a point at which the Ahmadi brand of Islam departs from other schools, especially those that lay claim to orthodoxy. The point of Mudathir here is that Jihad in Ahmadi understanding describes a set of actions that lead to progress in society. Islamic extremist groups choose concepts shared by other sects in the tradition and interpret them in ways that justify their atrocities.$^{89}$ Here, the Ahmadis are doing the exact opposite, reading very positive meanings into concepts such as jihad, and in the process selling the community as a peaceful form of Islam in an American religious market place in which most Islamic symbols are viewed negatively. This is a very good example of how the Ahmadiyya in Miami is countering Islamophobia.

In a similar vein, Abdul, a leading figure of the Jama'at said to me and a few of the Jama'at members present at the book fair during my fieldwork:

You know in this Jama'at, you can't go wrong, my brother. We are always seeking to educate people about Islam. There is so much to know that we can't exhaust it all in one sitting. The teachings that are given us in the Jama'at are very sound. They make sense. You see many of our brothers and sisters here. They are people of good morals because of the teachings of our Khalifa. He tells us to follow the laws of prophet Muhammed and the promised Messiah. When we meet to offer prayers, we are led by our Khalifa. He prays for us and we pray with him. He instructs us on what to do. That's why we're doing this. We will not pick up a weapon and fight. That's not what Islam teaches. That's not what a true Muslim does, my brother. Today, Ahmadiyya is known wherever we go through our MTA and books. Our Khalifa says the blessings of Allah will be there for all to see. Today, we are the ones bringing Islam to people, and many are realizing what true Islam is". He turns to the others briefly and resumes. "Soon the others will follow in our footsteps. Some of the news you hear about Islam and Muslims doing all these things. It's sad, my brother. It's sad. They don't

${ }^{89}$ Todd Green. The Fear of Islam. (Minneapolis: Fortress Press, 2015), 23. 
know. We have a leadership that is strong that stays true to what promised Messiah predicted in these times. We know this news about Islam will be there because of those who take it to the extreme. But we have been told to follow through in our Jihad by our Khalifa and show others the way to true Islam. Very soon, Insha Allah, the world will unite under true Islam and Ahmadiyya.".90

Here, the Ahmadiyya community is being portrayed as the true Islam and linked with many moral attributes that American society shares. By implication, the idea being conveyed is that there are other schools of Islam, but they propagate false forms, which stress actions such as picking up arms and fighting. It is only a matter of time when this positive form of Islam that Ahmadiyya expresses will triumph over the negative expressions.

\section{THE BLOOD DRIVE}

The Ahmadiyya community's efforts at portraying itself as "good Muslims" are not restricted to words. The community demonstrates the "goodness" of its brand of Islam through activities designed to benefit American society. One such activity is the blood drive. At one time the Imam spoke to me about a Blood Drive campaign the community organized on the Premises of Jackson North Memorial Hospital. This was part of the activities of the yearly Jama'at. The goal is to show support for the sick in the community by donating blood for those who may require it to stay alive. He commented on the success of the blood drive and seemed enthusiastic about repeating it the next year. He said, "We have a duty to the community where we find ourselves as Muslims to seek the good of the people who live there. Blood saves lives. You never know who will need it someday. So, we never shy away from donating blood too".

\footnotetext{
${ }^{90}$ Interview with Abdul from Milwaukee in Miami Book Fair. 11/18/2017
} 
On another day he mentioned the community's emphasis on engaging the larger American society in beneficial ways: 'Our Khalifa helps us to understand that the more one pursues virtue, the more spiritual a person becomes. Even today, as you have come here with your colleagues it is a virtue for us to teach you about Islam. We will not discriminate against anyone because if we do, that will not be what Islam and promised Messiah teach us. We hope to do more in the days ahead of us, God willing." Associating its brand of Islam with activities that support rather than take human life is one way in which the Ahmadiyya in Miami seeks to distance itself from the negative public image of Islam in the United States of America.

\section{Engaging The Online Community}

Minhas, a member of the Ahmadiyya community in Miami had urged me to subscribe to "True Islam online". This is an online site that enables the community to reach more people with its message. I investigated this online presence of the community. Each Saturday presented an opportunity for members to interact with an Imam on Periscope, a Twitter application that allowed for people to view footages of an Ahmadi Imam responding to several questions about Islam. The questions show up in comment boxes on any phone device. I could view the questions people had about Islam. They spanned many topics. Most, however, focused on the violence associated with Islam.

Imam Abdullah Dibba responded to this question asked which read, "what is the punishment for not to convert to Muslim?" Imam Dibba answered that, "many associate Islam with punishment and that is not the case. Islam is more about love and for punishment, only God Almighty can decide that." 
Another question posed during this live session on Periscope was on the relationship between Islam and racism. Imam Dibba responded saying, "there is no relationship between Islam and racism. Islam promotes unity and equality. Islam does not promote a creed or color of any human being over the other."

The Imam always made a point of emphasizing how the Ahmadiyya does not condone violence and terrorism. Other responses from people participating in the Scope (live footage with the Imam) maintained the negative views about Islam, often using derogatory comments. This reflects the ongoing clash between the "true Islam" the Ahmadiyya seeks to portray and the rather unflattering public perceptions. Many responses, however, show popular acceptance of the message the Ahmadis presented. The responses of Imam Dibba also point to the Ahmadiyya community's commitment to show that Islam is compatible with American way of life and regards values such as unity and equality.

\section{Public Places}

Another context for the Ahmadiyya engagement with people in order to educate them about Islam is Starbucks coffee shops. Ahmadi Muslims and Imams position themselves in these coffee shops wearing either a t-shirt or holding a placard on a table that reads: "I'm a Muslim. Ask me anything." Topics they discuss focus on any issue on Islam or an interesting happening in the United States. This helps to create rapport with many people who may not have had an encounter with a Muslim before. It also gives the impression Muslims are not different from people of other faiths in the USA. They like other Americans visit popular public spots such as Starbucks, Chipotle, Subway, or Tacobell.

Such moves by the Ahmadiyya are intended to convey the notion that not only is Islam 
non-violent, it is as American as any other religion of tradition. This is certainly an effort at combating Islamophobia in the USA.

\section{InVOLVEMENT With THE PUBLiC}

In the wake of the Parkland shooting at Marjory Stoneman High School in Florida, the Ahmadiyya Muslim Community had some members and leaders of the Jama'at participate with the students and families and the public in night vigils. Fareed Zafar and Imam Abdullah Dibba, who visited Hallandale Mosque that week, were among the few Ahmadis at one of the vigils. Imam Dibba spoke to a section of the students and the public, assuring them of the community's support while denouncing the violence that occurred. The students were later invited to the Baitul Naseer Masjid the following Friday for prayers. Every preparation was made to receive them that Friday. After the address and prayers by Imam Dibba and Imam Chaudry at the Mosque on Friday, the students shared memories of their lost colleagues and their appreciation for the Ahmadiyya Community. This action by the Ahmadiyya Community points was intended to show how their brand of Islam is tolerant, compatible with American values and eager to be part of larger society. 


\section{CHAPTER VII}

\section{CONCLUSION}

I have provided much information pertaining to the activities of the Ahmadiyya in South Florida. I have also presented the position of the Ahmadiyya community through its community engagements in South Florida that Islam is not violent. This includes the relation of the Jama'at's activities to the theories I discussed in this study. I also demonstrate how the interfaith dialogues, discourse and teachings, and community outreach support the Ahmadiyya's brand of Islam which is consistent with Western values and devoid of terrorism and the theories used in the study as well.

One driving force behind Ahmadiyya's activities is the shared sense among members that they need to respond to their call, "Love for all, hatred for none". This embodies what their Khalifa charges them to do "wherever they are, promote peace". Another driving force is the negative perception of Islam that is prevalent in the American media and the public because of the recent violence done in the name of Islam. The quest to combat this negative perception is among the reasons for the interfaith dialogues, the coffee shop meetings about True Islam, the community engagements, and online teachings and discussions. The Ahmadis perceive themselves to be the exemplar of what it is to be Muslim. They view their initiatives as steps needed to clearly demonstrate Islam. For them to be Muslim is not simply to hold beliefs and express them in words, but to do what as is required as stated in the scripture. The Jamaat makes a point of participating in events happening in the community. This is one way of showing that Islam is not alien to the larger community and

its concerns. These activities also offer them the opportunity to demonstrate their brand of Islam to help change the negative perception of Islam. The sense they intend to 
communicate here is that of an Islam that shares the public concerns, that shares the dream of peace and progress in society, that sees itself as American and that seeks to promote peace in the community.

The Miami Book Fair and the vigil and prayers held for the Parkland School victims are prime examples of how the Ahmadis position themselves to present Islam in a positive way. That they would participate in an event decrying violence betrays their underlying motive of branding themselves as an Islam that promotes non- violence. Their presence at these events showed that Islam did not condone violence in any way. My interview with Mudathir at the book fair in Miami reiterated this position by the Ahmadis. The Ahmadiyya would seize the opportunity it had to distinguish itself and its brand of Islam from other schools describing themselves as orthodox. That day Mudathir went further to distance Ahmadis from the other schools by emphasizing how Ahmadis face so much persecution from them. He concluded with a statement emphasizing how very paradoxical it was that in a time where Islam is challenged in America, the other sects of Islam are not actively engaged as they are at countering negative perceptions of Islam, especially, "the so-called true Muslims" that are antagonistic towards Ahmadis, who see the Ahmadiyya Community as representing a false expression of Islam. He also added that this is when we all need them to come out and show the world what Islam truly is.

Another important conclusion from the study relates to how the Ahmadis are challenging, through words and actions the perceptions that Islam is not compatible with American values and ways of life. The Ahmadis demonstrate through their interfaith dialogues and outreach initiatives that respect for people who differ from them, (including peace, tolerance, which are also worthy values in America), are cherished ideals of Islam, 
at least the Islam of which they are models of and models for. They argue, very forcefully, that these attributes make the religion compatible with the American way of life. The Ahmadis are also taking advantage of all the modern media forms available to spread their discourse to the American and global audiences. As Hamid Dabashi stated in his work, "Post-Orientalism," control over the modes of knowledge production determines who gets to tell the story. The Ahmadis use the same online social media tools that have been used by Islamic extremists to recruit and cause harm, to offer their understanding of Islam stressing how different they are from the popular negative rhetoric in the news.

As a missionary group, the activities of the Ahmadiyya also provides an opportunity for further research to understand how appealing its activities are with the communities they engage.

This different and positive narrative about Islam that the Ahmadiyya voices and reflects through its actions are what I have attempted to identify and demonstrate in this study. The Ahmadis present a counter-narrative about Islam which emphasizes how Islam is not associated with the violence extremism groups perpetuated in the name of religious piety. The thrust of the Ahmadi argument is that those who engage in violence in the name of religion must not refer to themselves as Muslims. 


\section{REFERENCES}

\section{Books}

Ahmed, Akbar. Journey into America. The Challenge of Islam. Washington. Brookings Publications, 2007.

Ali Hirsi, Ayaan. Infidel. New York: Free Press, 2008.

Allen, Chris. Islamophobia. New York. Ashgate Publishing, 2010.

Arthar, Shahid. Reflections of an American Muslim. Chicago. Kazi Publications, 1994.

Atwan, Abdel Bari. Islamic State. The Digital Caliphate. California. University of California Press, 2015.

Baumann, Gerd. The Multicultural Riddle. Rethinking National, Ethnic and Religious Identities. London. Routledge, 1999.

Bruce, Steve. Religion and Rational Choice. A Critique of Economic Explanations of Religious Behavior. New York. Oxford University Press, 1993.

Bunzl, Matti. Anti-Semitism and Islamophobia. Hatreds Old and New in Europe. Chicago. Prickly Paradigm Press, 2007.

Cesari Jocelyne. Muslims in the West After 9/11. Religion, Politics and Law. New York. Routledge Taylor and Francis, 2010.

Cole, Juan. Engaging the Muslim World. New York: Palgrave Macmillan, 2009.

Dabashi, Hamid. Post-Orientalism. Knowledge and Power in Time of Terror. New York. Transaction Publishers, 2009.

Esposito, John L. Islam. The Straight Path. New York. Oxford University Press, 1998.

Green, Todd H. The Fear of Islam. An Introduction to Islamophobia in the West. Fortress Press. Minneapolis, 2015.

Haddad, Yvonne Yazbeck, ed. The Muslims of America. New York. Oxford University Press, 1991. 
Haddad, Yvonne Yazbeck, and John L. Esposito, eds. Muslims on the Americanization Path? New York. Oxford University Press, 1998.

Halliday, Fred. Two Hours that Shook the World. September 11, 2001. Causes and Consequences. Saqi books, 2002

Hughes W. Aaron. Muslim Identities. An Introduction to Islam. Columbia University Press. New York, 2013.

Kosezegi, Michael A., and J. Gordon Melton, eds. Islam in North America. A sourcebook. New York. Garland, 1992.

Kumar, Deepa. Islamophobia and the politics of Empire. Chicago. Haymarket, 2012.

Meer, Nasar and Tariq Modood. Refutations of Racism in the Muslim Question. Patterns of Prejudice. Routledge, 2009.

Otterbeck, Jonas and Pieter Bevelander. Islamophobia. A Study of the Concept, Young People's Attitudes and Young Muslim's Vulnerability. Stockholm. Forum för levande historia, 2006.

Ouis, Pernilla and Anne Sofie Roald. Muslim in Sweden. Stockholm. Wahlström \&Wikstrand,2003.

Pipes, Daniel. Militant Islam Reaches America. New York. Norton, 2002.

Qazwini, Imam Hassan. American Crescent. A Muslim Cleric on the Power of his Faith, the Struggle Against Prejudice, and the Future of Islam and America. New York. Random House, 2007.

Rattansi, Ali. Racism. A Very Short Introduction. Oxford University Press, 2007.

Rashid, Qasim. The Wrong Kind of Muslim. United States. AyHa Publishing, 2013.

Robertson, Roland. The Economization of Religious Reflections on the Promises and Limitations of the Economic Approach. London. Sage, 1992.

Said, Edward. Orientalism. New York. Vintage Books, 1979. 
Said, Edward. Covering Islam. How the Media and the Experts Determine How We See the Rest of the World. London. Vintage Books, 1997.

Shahram Akbarzadeh and Samina Yasmeen, eds. Islam and the West. Reflections from Australia. Sydney. University of New South Wales, 2005.

Smith, Jane. Islam in America. New York. Columbia University Press, 2010.

Spencer, Robert. Islam Unveiled. Disturbing Questions about the World's FastestGrowing Faith. San Francisco: Encounter Books, 2003.

Stern, Jessica and J.M Berger. ISIS. The State of Terror. HarperCollins Publishers, 2015.

The Runnymede Trust. Islamophobia a Challenge for Us All. Commission on British Muslims and Islamophobia. London. Runnymede Trust, 1997.

Ukah, Asonzeh. Advertising God. Nigerian Christian Video Films and the Power of Consumer Culture. Brill, 2003.

Valentine, Simon Ross. Islam and the Ahmadiyya Jama'at. History, Belief, and Practice. New York. Columbia University Press, 2008.

Warner, Michael. Publics and CounterPublics. New York. Zone Books, 2002.

Weiss, Michael and Hassan Hassan. ISIS. Inside the Army of Terror. New York. Regan Arts, 2015.

Yasmeen, Samina, ed. Muslims in Australia. The Dynamics of Exclusion and Inclusion. Melbourne. University Press, 2006.

\section{Online Sources}

Ali Hirsi, Ayaan, Chahla Chafiq, Caroline Fourest et al., Together Facing the New Totalitarianism. BBC News (UK) March 1, 2006. http://news.bbc.co.uk/2/hi/europe/4764730.stm. 
Hatuqa, Dalia. Islamophobia Prompts Muslims to Engage in US Democracy. Aljazeera. May 4, 2018.

Hanson, John. Jihad and the Ahmadiyya Muslim Community. Nonviolent Efforts to Promote Islam in the Contemporary World. The Journal of Alternative and Emergent Religions. Vol 11. No. 2. November 2007.

Hazrat Mirza Masroor Ahmad. The Difference Between True Islam and Extremist Groups. The Review of Religions. January 2015.

Lean, Nathan. The Islamophobia Industry. How the Right Manufactures Fear of Islam. Pluto Press, 2012.

Marzouki, Nadia. Islam. An American Religion. Columbia University Press, 2013.

Michaud, Anne. Muslim Community responds to Paris Attacks. January 16, 2015.

P.W. Singer and Emerson Brookings. Terror on Twitter. How ISIS is Taking War to Social Media and Social Media is Fighting Back. Popular Science. December 11, 2015.

Schluer, Ulrich interviewed by Julie Hunt, Anti-Minaret Campaigner Puts Case. (October 6, 2009). http://www.swissinfo.ch/eng/multimedia/video/Anti-minaret_campaigner.

Speckhard, Anne and Ardian Shajkovci. Breaking the ISIS Brand Counter-Narratives. Ethical Considerations in Fighting ISIS Online. Vox Pol. March 7, 2018.

State Multiculturism Has Failed, says David Cameron. BBC News, UK. February 5, 2011. http://www.bbc.co.uk/news/uk-politics-12371994.

Welch, Michael. Scapegoats of September $11^{\text {th }}$. Hate Crimes and State Crimes in the War on Terror. Rutgers University Press, 2006. 


\section{Interviews and Lectures}

Aslan, Reza. Confronting Islamophobia in the U.S and Abroad. Florida International University, Miami, Florida. October 10, 2017.

Dibba, Abdullah. Ask an Imam Anything. Islam Teachings about Racism and Equality for All. True Islam USA. January 21, 2018. Periscope. https://www.periscope.tv/w/1ZkKzdbmXmWJv?q=true+Islam

Dibba, Abdullah. Muslim Imam at Parkland School Shooting. True Islam USA. February 16, 2018. Periscope. https://www.periscope.tv/w/1RDGldXYzMkGL?q=true+Islam

Haneef, Azhar. Militant Extremism in the Muslim World. Lecture presented at Florida International University, Miami, Florida. October 31, 2017.

Mudathir, interview by Emmanuel Dennis, Miami Book Fair, November 18, 2017.

Mudathir, interview by Emmanuel Dennis, Baitul Naseer Mosque, November 14, 2017.

Nazir, interview by Emmanuel Dennis, Miami Book Fair, November 19, 2017.

Rahman, Abdul, interview by Emmanuel Dennis, Miami Book Fair, November 18, 2017.

Suraleigh, Zafar, interview by Emmanuel Dennis, Baitul Naseer Mosque, November 14, 2017.

Suraleigh, Zafar, interview by Emmanuel Dennis, Miami Book Fair, November 18, 2017. 